\title{
Determination of Suitability to Cheese Standards of Somatic Cell Counts in Milk obtained from Dairy Cows having Different Body Condition Scores
}

\author{
Alirıza Şahiin ${ }^{1}$, Murat Çimen ${ }^{2 *}$ \\ ${ }^{1}$ Provincial Directorate of Food, Agricultural and Livestock, Tunceli, Turkey \\ e-mail:alirizas6262@gmail.com \\ ${ }^{2}$ Food Engineering Department, Faculty of Engineering, Munzur University, Tunceli, Turkey \\ *Corresponding author: mcimen19@gmail.com
}

\begin{abstract}
In the study, milk samples were gathered from 30 Brown Swiss cows were grown at the special dairy farm and analyses were done at the same farm's lab. In the research, cows having three different body condition score $(2,3,4)$ was compared for determination of differences in terms of somatic cell count in milk. There are three different condition groups as Condition 2(weak), Condition 3 (normal) and Condition 4 (Fatty) in the study. The SCC of milk was compared with the desired standards for cheese production ( $\max .500 \times 10^{3} \mathrm{cell} / \mathrm{mL}$ ) by using one-sample statistical $t$ test. According to the study results, somatic cell counts of all condition scores (2,3 and 4) for Brown Swiss cattle were compatible with reference values of quality cheese making. We can say that BCS $2\left(100 \times 10^{3}\right.$ per $\left.\mathrm{mL}\right), \mathrm{BCS} 3\left(80 \times 10^{3}\right.$ per $\left.\mathrm{mL}\right)$, and BCS $4\left(104 \times 10^{3}\right.$ per $\left.\mathrm{mL}\right)$ for Brown Swiss cattle were suitable for quality cheese production.
\end{abstract}

KEY WORDS: Somatic Cell, Milk, Cow, Cheese Standard

\section{INTRODUCTION}

Somatic cells are an important component in raw milk, and SCC is used as an indicator of raw milk quality. Recently, there has been increasing interest on milk SCC [1]. Milk SCC can greatly impact profit of milk products because higher SCC rates leads to lower cheese yield [2]. SCC is therefore called economic parameter. Suitable hygiene will ensure high quality milk products obtained from raw milk. The somatic cell level in conventional milks is due to hygiene of raw milk [3] as affected by a lot of factors such as lactation stage and feeding practices and environmental conditions. It is known that cow factor affects dairy product processing in terms of their having different SCC. However, it is not known which body condition score is more suitable for desired cheese production. It is necessary to determination and classification of conventional raw milk in terms of SCC basis for desirable cheese composition and quality [4].

The variations of somatic cell counts in raw cow milk from different animal material can offer different opportunities for the made of cheese varieties [5]. Milk SCC significantly affected firmness and flavor of dairy products such as cheese [6]. It must be known that which raw cow milk should be preferred according to SCC for the producing of cheese varieties. The aim of this paper is to investigate the suitability of milk from cows having three different body condition score for the production of different cheese varieties. 


\section{MATERIALS AND METHODS}

\section{Animal}

In the research, Brown Swiss cows (10 cows per group) having three different body condition score $(2,3,4)$ was compared for determination of differences in terms of somatic cell count in milk. There are three different condition groups as BCS 2(weak), BCS 3 (normal) and BCS 4 (Fatty) in the study.

\section{Season and study area}

In the study, the daily milk samples were obtained during summer season from special dairy farm in Bursa Province of Turkey.

\section{Milk analysis}

The milk samples were put into vessels and stored $4^{\circ} \mathrm{C}$ for analyzing procedure. The somatic cell counts within taken milk samples were determined by the standard analysis (Microscopic count) method.

\section{Statistical analysis}

The SCC of raw cow milk was compared with the standard (max. $500 \times 10^{3}$ cell/mL) of cheese production [7] by using one-sample t-test [8] by SPSS 18.0 package program [9].

\section{RESULTS}

The statistical control analysis (one sample t test results) for the SCC level of raw milk obtained from different body condition scores were given in Table 1, 2 and 3. It is also possible to see the results of descriptive statistics such as mean, std. deviation and std. error from the table.

\section{BCS 2 and suitability test}

The SCC of milk obtained from BCS 2 was compared with the cheese standards in Table 1.

Table 1 . The suitability test of BCS 2 for cheese production standard

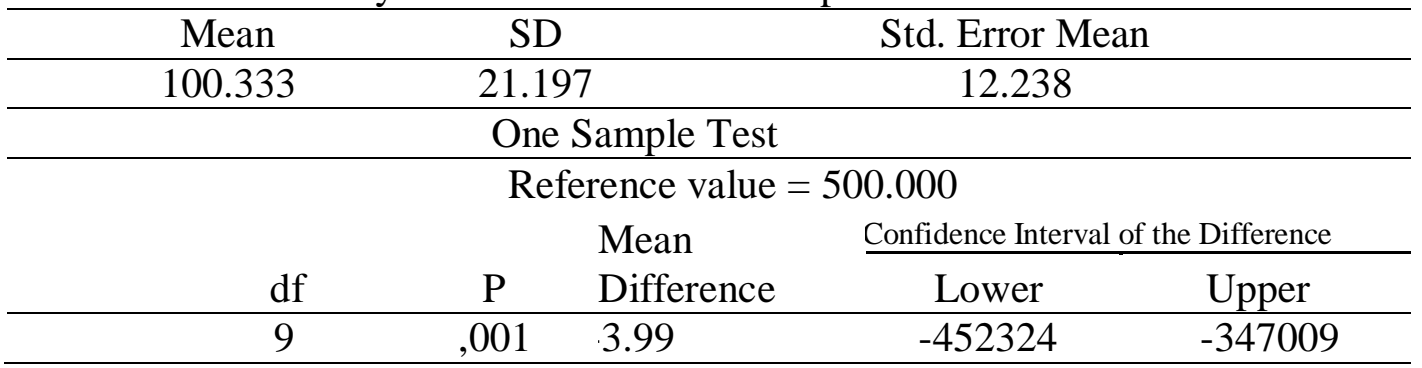

Obtained somatic cell count $\left(100 \times 10^{3}\right.$ per $\left.\mathrm{mL}\right)$ for BCS 2 was statistically lower $(\mathrm{p}<0.01)$ than announced reference value $\left(\max .500 \times 10^{3} \mathrm{cell} / \mathrm{mL}\right)$ for quality cheese production. According to research findings, quality cheese can be produced from milk of cows having body condition score 2 . From the results, we can say that the leanness is not risky and also it has advantages for quality cheese production. If quality cheese making is desired, BCS 2 is suitable score.

\section{BCS 3 and suitability test}

As shown the Table 2 , SCC $\left(80 \times 10^{3}\right)$ for BCS 3 was compatible with the standards (max. $500 \times 10^{3} \mathrm{cell} / \mathrm{mL}$ ). From the results of study, desired cheese quality according to standard can be obtained from milk of cows having BCS 3. There is no need to extra manipulation of the raw milk for quality cheese production. The milk samples for this score are very suitable for cheese standards. 
Table 2. The suitability test of BCS 3 for cheese production standard

\begin{tabular}{|c|c|c|c|c|}
\hline Mean & SD & \multicolumn{3}{|c|}{ Std. Error Mean } \\
\hline 80.666 & 87.3 & \multicolumn{3}{|c|}{50.44} \\
\hline \multicolumn{5}{|c|}{ One Sample Test } \\
\hline \multicolumn{5}{|c|}{ Reference value $=500.000$} \\
\hline \multirow{2}{*}{$\frac{\mathrm{df}}{\mathrm{q}}$} & & Mean & \multicolumn{2}{|c|}{ Confidence Interval of the Difference } \\
\hline & $\mathrm{P}$ & Difference & Lower & Upper \\
\hline 9 & 001 & 4.19 & -441036 & -397629 \\
\hline
\end{tabular}

\section{BCS 4 and suitability test}

Table 3 shows the results of statistical control for cows having BCS 4 . Determined somatic cell level $\left(104 \times 10^{3}\right.$ per $\left.\mathrm{mL}\right)$ for BCS 4 was statistically lower $(\mathrm{p}<0.01)$ than critical threshold ( $\max .500 \times 10^{3}$ cell $/ \mathrm{mL}$ ) for quality cheese making. According to research data, quality cheese can be produced from milk of cows having condition score 4. In light of the obtained findings, we can say that BCS 4 is suitable score for quality cheese making. From the results, we can say that the adiposity is not risky and quality milk has low SCC for cheese making may obtain from fatty animals.

Table 3. The suitability test of BCS 4 for cheese production standard

\begin{tabular}{|c|c|c|c|c|}
\hline Mean & SD & \multicolumn{3}{|c|}{ Std. Error Mean } \\
\hline 104.333 & 12.5 & \multicolumn{3}{|c|}{7.2} \\
\hline \multicolumn{5}{|c|}{ One Sample Test } \\
\hline \multicolumn{5}{|c|}{ Reference value $=500.000$} \\
\hline \multicolumn{5}{|c|}{ Mean $\quad$ Confidence Interval of the Difference } \\
\hline df & $\mathrm{P}$ & Difference & Lower & Upper \\
\hline 9 & ,001 & 3.95 & -42672 & -36460 \\
\hline
\end{tabular}

\section{DISCUSSION}

In this paper, statistical control on SCC rates of milk obtained from cows having different body condition scores was applied for determination of suitability to quality cheese production. We thought that if there is discrepancy between data obtained from different body condition scores, there will be an opportunity to get interesting interpretations.

High SCC (greater than 200,000 cells $/ \mathrm{ml}$ ) is not favorable for consumer and human consumption [10]. If the SCC exceeds announced threshold, it is considered unhealthy for consumers and this high critical threshold is not suitable for their demands. For human health, SCC levels should be at a minimum threshold. The obtained mean value was also in line with European Union (max. 400,000 cells/ml), Canada (max. 500,000 cells/ml) and USA (max. 750,000 cells $/ \mathrm{ml}$ ) standards [11]. Although there are studies on the somatic cells, there are no studies on the compatibility of somatic cells with reference values of cheese and product quality standards.

It was seen that the condition score did not change the somatic cell counts related to cheese making. The differences in body fat tissue ratios of the dams have not made a significant negative impact on SCC. According to Işgın and Cimen [12], ratios of body fat depots do not change somatic cell levels. In the study, it was aimed to determine which body condition score is more suitable for quality cheese making. In the light of this information, it is understood that different body condition scores caused from different fat tissue ratios do not have a negative effect on somatic cell levels of raw milk obtained from dairy cows. 
According to findings obtained from study, similarly to the low body condition score (2), the normal (3) and fatty (4) scores also are characterized by their advantageous properties associated with low SCC. The fact that differences in body condition scores do not have a negative effect on milk quality caused from somatic cell counts is an advantage in terms of milk sector. Milk producers thinking to their profits in terms of risk from high somatic cell levels do not need to pay attention to differences in body condition scores. Since cheese production is important for dairy sector, all animal and environmental factors on milk quality should be investigated. New and striking findings obtained from statistical control are needed for cheese making sector.

\section{CONCLUSION}

According to findings from the research, it can be said that all body condition scores $(2,3$ and 4) for Brown Swiss cattle were suitable for reference values of quality cheese making. To sum up, quality cheese can be produce from raw milk obtained from Brown Swiss cows having different body condition scores.

\section{REFERENCES}

[1] Bansal, B.K, Hamann, J., Lind, O., Singh, S.T., \& Dhaliwal, P.S. 2007. Somatic cell count and biochemical components of milk related to udder health in buffaloes. Italian Journal of Animal Science. 6(2), 1035-1038.

[2] Le Marechal, C., Thiery, R., Vautor, R., \& Le Loir, Y. 2011. Mastitis impact on technological properties of milk and quality of milk products - a review. Dairy Science and Technology. 91, 247-282.

[3] Zakeri, A., Saberi, M., Hussain, O.K., Aboutalebi, S., \& Chang, E. 2018. Developing a quality index for managing the quality of raw milk in the farm. Proceedings of International Conference on Computers and Industrial Engineering, CIE.2018December

[4] Murphy, S.C., Martin, N.H., Barbano, D.M., \& Wiedmann, M. 2016. Influence of raw milk quality on processed dairy products: How do raw milk quality test results relate to product quality and yield? Journal of Dairy Science, 99 (12), 10128-10149.

[5] Li, N., Richoux, R., Boutinaud, M., Martin, P., \& Gagnaire, V. 2014. Role of somatic cells on dairy processes and products: a review. Dairy Science Technology, 94 (6), 517-538.

[6] Rayan, A.A., Kaláb, M., \& Ernstrom, C.A. 1980. Microstructure and rheology of process cheese. Scan Electron Microscope, 3,635-643.

[7] Mistry, V.V., \& Kosikowski, F.V. 1988. Yield and quality of Cheddar Cheese from high somatic cell milk supplemented with retentate to varying concentrations or Directly Ultra filtered. Journal of Dairy Science. 71, 2333-2341.

[8] Çimen, M. 2015. Fen ve Sağlık Bilimleri Alanlarında Spss uygulamalı Veri Analizi. Palme Yayıncılık, Yayın No: 905, ISBN: 978-605-355-366-3. Sıhhıye, Ankara.

[9] Ntoumanis, N.A. 2005. Step-by-Step Guide to SPSS for Sport and Exercise Studies. Published in the USA and Canada by Routledge Inc. ISBN: 0-415-24978-3. (Print Edition) 29 West 35 th Street, New York, NY 10001.

[10] Kaşıkçı, G., Çetin, Ö., Bingöl, E.V., \& Gündüz, M.C. 2011. Relations between electrical conductivity somatic cell count, California mastitis test and some quality parameters in the diagnosis of subclinical mastitis in dairy cows. Turkish Journal of Veterinary Animal Science, 36(1), 49-55.

[11] Robinson, R.K. 2005. Dairy microbiology handbook. The microbiology of milk and milk products. $3^{\text {rd }}$ ed. Pp.784. Wiley interscience publications. ISBN: 0-471-385964. 
[12] Işgın, B., \& Çimen, M. 2016. Total Bacteria and Somatic Cell Counts in Milk from Cows at Different Breed and Body Condition Scores. International. Congress Natural Engineering Science. Abstr. Book. P.50. 1-5 September 2016. Macedonia. 